\title{
The Interorganizational Level in the Learning Continuum: Analytic Conceptual Scheme
}

\author{
Anelise R. Mozzato ${ }^{1}$, Claudia C. Bitencourt ${ }^{2} \&$ Denize Grzybovski ${ }^{1,3}$ \\ ${ }^{1}$ Passo Fundo University UPF, Passo Fundo, RS, Brazil \\ ${ }^{2}$ Vale of the Sinos University - UNISINOS, São Leopoldo, RS, Brazil \\ ${ }^{3}$ Regional University Northeast of the Rio Grande do Sul State /UNIJUÍ, Brazil \\ Correspondence: Anelise R. Mozzato, Passo Fundo University UPF, Campus I UPF-BR 285, Av. São José, Zip \\ Code: 611, 99001-970, Passo Fundo, RS, Brazil. E-mail: anerebe@upf.br
}

Received: February 1, 2015

Accepted: February 25, 2015

Online Published: March 25, 2015

doi:10.5539/ibr.v8n4p94

URL: http://dx.doi.org/10.5539/ibr.v8n4p94

\begin{abstract}
The objective of this theoretical essay is to propose the inclusion of the interorganizational learning level (IOL) in the analytical model of learning, legitimizing the proposal to Crossan et al. (1995), Knight (2002) Bapuji and Crossan (2004) and Knight and Pye (2005). The IOL in the learning continuum process was identified by Crossan et al. (1999), but not included in the analytical conceptual framework. This study is done for this reason, besides the intention of enhancing this fourth level of learning. The said proposal contributes to the advancement of knowledge on management and to understand the IOL in interorganizational relationships, also presenting the categories of analysis to studies in this level of theme.
\end{abstract}

Keywords: cooperation, interorganizational learning, interorganizational relations, organizational learning

\section{Introduction}

This theoretical essay is intended as contribution to study of interorganizational learning. The growing need for different forms of interorganizational relationships has been considered a feasible strategy to face increasingly uncertain environments (Human \& Provan, 1997). Studies on different forms of productive agglomerations have become more important in literature, a subject for increased discussion. Thereby interorganizational cooperation gains space in the world economy due to the emergence of new and different organizational configurations such as Local productive arrangements (LPA), clusters, networks, etc. In such forms of organization the relationships between different role players end in interaction and learning, especially learning-by-interacting (Lunduall, 1992). In the context the comprehension of the interorganizational learning processes (IOL) between the different role players becomes a relevant subject, particularly in view of the fact that it is a complex, little explored phenomenon that opens an interesting space for diverse investigations and for many years (Inkpen \& Tsang, 2007).

Lately organizational learning (OL) has been intensely studied. Although it is amply accepted and OL is given a place of importance in the strategic performance of organizations, the conceptual complexity and diversity that permeates such studies are not denied (Fiol \& Lyles, 1985; Easterby-Smith \& Lyles, 2003; Ruas, Antonello, \& Boff, 2005; Bitencourt, 2005; Antonacopoulou \& Chiva, 2007; Amorim \& Fischer, 2009), as is the case with IOL. Throughout the last ten years the focus of studies on organizational learning (OL) have moved constantly away from interorganizational learning to multi and inter organizational learning, without attaining conceptual depth (Engestro \& Kerosuo, 2007). Not only does it deal with a complex subject but it also encompasses a plurality of concepts in view of the tenuous difference between them and the superposition of theories in the studies on interorganizational relations (Cropper, Ebers, \& Huxham, 2008). Notwithstanding, IOL is still an incipient field for analysis.

Even though IOL raises many questions and studies do not have presented yet an analytic and conceptual scheme that will enable it to be understood as a continuum of individual, group, organization and interorganizational learning. Amongst the many existing studies there is a perception that this fourth level of learning is considered, quoted and studied without a framework such as that presented by Crossan et al. (1999), explicitly presenting this level in a continuum. In view of this reality our intention is to use the contributions offered by these studies, 
and emphasize a process and dynamic interlinking view between the four learning levels, these being the individual, group, organization and interorganizational levels. It is in this sense, by emphasizing an explicit, schematically inclusive approach that this study's innovating aspect can be perceived.

In view of the above the scope of analysis of IOL, this being understood to be part of a continuum of organizational learning at a level identified by Crossan et al. (1995) but not included in the analytic conceptual framework presented by the authors. Based on Crossan et al. (1999) framework this theoretical essay aims at proposing the inclusion of the interorganizational learning level, thereby legitimizing the one proposed by Crossan et al. (1995), Knight (2002), Bapuji and Crossan (2004) and Knight and Pye (2005) and advancing the study with the presentation of analysis categories for the interorganizational dimension.

The proposition is justified because the interorganizational level is the least referred to in studies on Management, and contributes considerably to the understanding of IOL in interorganizational relations. Finally it is understood that the proposal is relevant in that it contributes to understanding learning at every level (individual, group, organization and interorganizational) as it presents the analytic categories for this last level of learning.

The theoretical study is structured in five parts along this line of thought. The fist, this introduction, is followed by the second one, which shows the theoretical references and emphasizes the interorganizational relationships and learning at different levels. In the third part an analytic conceptual proposal for the inclusion of the fourth level of learning in the organizations is proposed. The fourth part highlights the possibilities and limitations of using the proposed framework in empirical research. The study is finalized with the final comments and sources used in this study.

\section{Interorganizational Relations and Interorganizational Learning}

The choice of dynamic strategies for organizations, in creating, maintaining and renewing competitive advantages is currently under discussion. In this context it is necessary to consider new, different forms of organizational configuration, particularly interorganizational cooperation relations. For Fayard (2008), in this context the cooperation networks emerge as one of the main management alternatives.

Different forms of interorganizational relations can be answered to market requirements, considering that the speed of change in the business world and consequent quest for competitivity call for a high level of quality, innovation and low costs. In this sense, Jarillo (1988) defines the network as a new organizational configuration, which as such must be considered in strategic terms, in which the cooperative relations may be the source of competitive forces. Subsequently Jarillo (1993) shows how a different way of organizing relationships between companies can result in consistently higher business performance in specific industries. The author makes it clear that understanding a network is complex but is a competitive strategic alternative and reinforces the fact that the atomistic vision of the traditional model in which each participant is "facing the world alone" may not be the most efficient way of competing. In this context, Balestrin and Verschoore (2008) stress the importance of collective strategies showing many companies to have increased their productivity by fashioning networks or other cooperation strategies.

Pittaway et al. (2004) show that recent competitivity studies have emphasized the importance of business networks for innovation, which, even if the insights on them may appear fragmented show the networks to be an emerging possibility (Jarillo, 1993). The author touches on network cooperation as a way of competing, with companies cooperating even though they are competing. In fact these two dimensions are superimposed. However, Todeva (2006) emphasizes that the networks are predominantly collaborative and involve some form of sharing of resources. Synthesizing, classics such as Jorde and Teece (1989), Jarillo (1993), Brandenburger and Nalebuff (1996), and Brazilian researchers such as Shima (2006) and Baiardi (2008) state that cooperation and competition also coexist in these new structural configurations. This fact offers the idea of "coopetition" a word coined by Brandenburger and Nalebuff (1996), which means thinking of cooperation in processes that coexist with competition. However, trust is considered essential in cooperation processes, much it coexists with competition.

It becomes obvious that the incorporation of the prospect networks acquires an important role in understanding the behavior of organizations in these new times in their different interorganizational relations. Presently, in seeking a new notion of competitivity, collaborative actions, in their most varied forms are very pertinent. The alliances "are strategic because they have been established with specific interests by the parties involved, and therefore can involve rival firms. In this sense cooperation and competition are simultaneous, dynamic and contradictory" (Shima, 2006, p. 356). 
Different interorganizational arrangements have shown gain to the involved economic agents. As per Jorde and Teece (1989), these new organizational arrangements enable increased access to new knowledge, easing OL access to new technologies, the innovation process and allowing increased technological capacity. Interorganizational collaboration is related to a number of important results, amongst which sharing, wherein the knowledge transfer is made easy. Therefore collaboration eases the creation of new knowledge, producing innovation and new solutions, and can help organizations to occupy a more central and competitive position with the possible coexistence of collaboration and competition offsetting those organizations that work in isolation.

Therefore it may be said that the organization that arrive at different organizational configurations through interorganizational relations, frequently also seek to facilitate the diffusion of knowledge (ex: Inkpen \& Beamish, 1997; Bowell, 1998; Inkpen, 2000; Lane, 2001; Child, 2001; Holmqvist, 2004; Knight, 2005; Inkpen \& Tsang, 2007; Easterby-smith, Lyles, \& Tsang, 2008; Macdonald \& Crossan, 2010) research showing the possibility of sharing knowledge and IOL through collaborative activity also in complex environments.

The importance of the information flow becomes evident and thereby of knowledge, which is facilitated in an interorganizational cooperation system. Thus Shima (2006) stresses the importance of sharing intercorporate resources and information, and the greater flow of information required by global corporations. To this end Shima (2006) states: "The company's source of competitivity does not come from outside but rather in its capacity to find, in a more general sense, creative solutions-such as new processes, product differentiations, and especially, new organizational and/or institutional arrangements" (p. 347).

However, the importance of IOL is stressed in view of the fact that learning is not only a motive for strategic alliances but also necessary to effective cooperation (Larsson, Bengtsson, Henriksson, \& Sparks, 1998). Learning and collaborative innovation, enabled by interorganizational relations, stand out as essential for the competitive future of the different organizational configurations. Within this context the ability to learn and innovate and diffuse knowledge also becomes essential in interorganizational cooperative relations. Likewise the importance of trusted sharing of information and knowledge management becomes evident.

Powell (1998) is a classic on learning through collaboration. After discussing the double face of collaboration the author uses examples from the field of biotechnology and the pharmaceutical industries to show pertinent ways of working with knowledge management with a view to sharing information and learning in a collaboration network, highlighting the fact that a company participating of a network has a greater innovative capacity than a company working individually. Finally he makes it clear that collaboration and learning through collaboration happens in many different ways and that there is a need to question and seek "routes" that point towards knowledge promotion and management.

Hardy, Phillips, and Lawrence (2003) discuss the effects of interorganizational collaboration stating that it does not merely transfer knowledge but generates new knowledge. The study on interorganizational networks and policies suggests that collaboration may help organizations to achieve a more central position compared to other organizations. The results of research carried out by the authors indicate the importance of developing a better understanding of the variety of effects that collaborative work can achieve.

There is a growing interest in understanding how interactive processes, especially in agglomerated micro, small and medium sized companies interfere to reinforce learning in companies (Cassiolato, 2004). Based on the role and importance of these productive agglomerations it can be perceived that the use of synergies generated considerably increases the chances of survival and growth thus generating lasting competitive advantages (Amato Neto, 2000; Cassiolato \& Lastres, 2003).

However, information and knowledge exchange in collaborative form can be effected in different ways. To this end Powell (1998) states there are various questions as to the best way to collaborative learning. Network creation generates a new organizational configuration which can supply a platform for organizational learning allied to partners with access to new knowledge (Inkpen, 1998). Thereby network learning is a complex phenomenon that clears an interesting space for various investigations into mutual knowledge and learning (Inkpen \& Tsang, 2007), as well as into widening the discussion of interorganizational learning.

\subsection{Organizational and Interorganizational Learning}

It is well known that OL literature has advanced lately. As stated by Antonello and Godoy (2010; 2011), both the number of publications and the discovery of new dimensions of analysis on the subject have increased. Such advances make the authors fear the loss of specificity of the concept itself. "The debate, in its widely encompassing dimension, calls on various theoretical, psychological, sociological cultural, historical and methodological fields, apart from management in itself" (Antonello \& Godoy, 2010, p. 313). They stress that just 
as in studies on interorganizational relations, in OL "the dominant concepts are strongly influenced by the approach through traditional scientific management" (Antonello \& Godoy, 2010, p. 313).

Since OL is not the main focus in this study we do not intend to delve more deeply into it, considering that this has already been done by Fiol and Lyles (1985), Argyris and Schön (1978), Dierkes et al. (2001), Bitencourt (2001), Easterby-Smith and Lyles (2003), Antonello (2004), and more recently, Argote (2011) and Antonello and Godoy (2011).

Finally we must highlight that we recognize, as do Easterby-Smith et al. (2004), Antonacopoulou and Chiva (2007), Antonello and Godoy (2011) and Crossan, Maurer and White (2011) that much still must be learned about OL. Crossan et al. (2011) encourage the expansion of the scope of analysis of learning processes. However since we consider it is important to avoid the error of not considering the contributions of existing OL studies we have emphasized the matter of the already existing state-of-the-art due to which the following sub-chapter revises classical OL concepts that are already perceived as important in understanding the inclusion of interorganizational learning as the fourth level according to the logic developed in Crossan at al. (1999), Knight (2002), Bapuji and Crossan (2004) and Knight and Pye (2005).

\subsubsection{Organizational Learning}

To most organizational learning theoreticians such as Easterby-Smith, Burgoyne, Araujo (2001), Ruas et al. (2005), Argote (2011) and Antonello and Godoy (2011), the matter of how to promote OL has not been covered sufficiently. Despite the fact that OL has being studied since 1964 the subject began to be more known with Argyris and Schön (1978) and only gained popularity in 1990 after the work of Peter Senge was published.

Crossan et al. (1999) analyze organizational learning by proposing a framework (Figure 1) and identifying four learning processes (intuition, interpretation, integration and institutionalization) at three levels of analysis (individual, group and organizational). They point out that such levels are permeated (or joined) by both social and psychological processes.

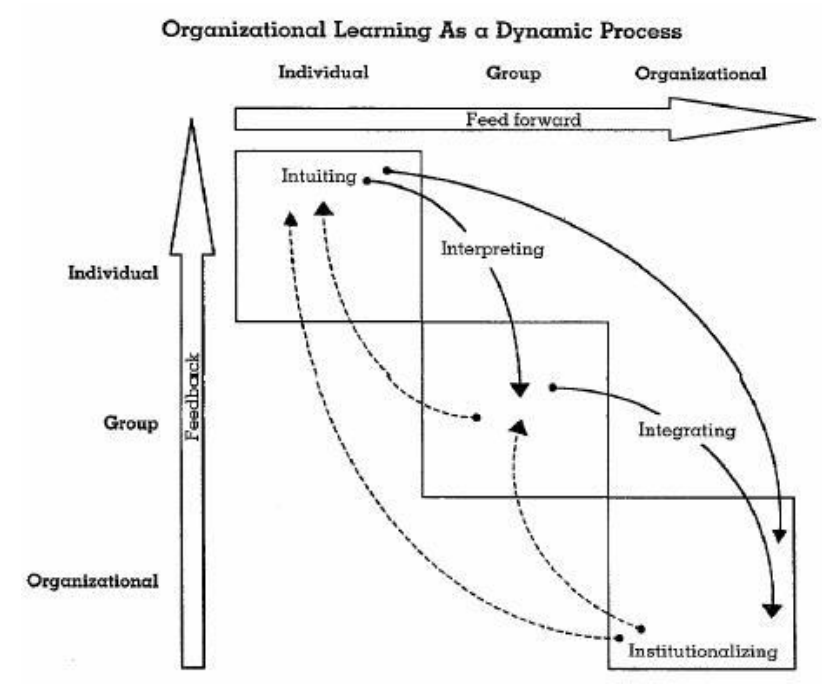

Figure 1. Organizational Learning as a dynamic process

Source: Crossan et al. (1999, p. 532).

Although Crossan et al. (1995) identify the fourth level of learning (interorganizational) even years later Crossan et al. (1999) had not included it in their proposed framework. However, they pint out that amongst other implications OL is more than a simple data, information or knowledge transfer, besides which changes in knowledge do not necessarily lead to changes in actions.

OL is not the focus of this study but underpins another dimension of the concept, the interorganizational one. Therefore the interorganizational dimension will be considered a "continuum" for understanding the interorganizational dimension, without denying the intersection between both (OL and IOL). Holmqvist (2003; 2004; 2009) states that in this sense the interrelation between intra and inter organizational learning cannot be 
ignored and that they can be analyzed independently (Larsson et al., 1998). Holmqvist (2003) clearly states that learning stems from the organizations interactions with its context, which also includes the interactions with other organizations, assuming that they learn by organizational interaction (Hedberg, 1981).

\subsubsection{Interorganizational Learning}

Studies on IOL mainly began at the end of the nineties (Larsson et al., 1998). The authors aver that in spite of the recognition of the fact that collaborative relationships are part of the organizational configurations these last decades, the comprehension concerning learning alliances to date have been limited.

More recently researchers such as Hardy et al. (2003), Greve (2005), Engestro and Kerosuo (2007), Inkpen and Tsang (2007), Nooteboon (2008) amongst others point out the need to deepen studies on IOL. Researchers such as Estivalete (2007), Estivalete et al. (2008), Balestrin and Verschorre (2008) and Mozzato and Bitencourt (2014) indicate the same need. Recently Antonello and Godoy $(2009 ; 2010 ; 2011)$ show how research on organization networks and learning communities are relevant and call for more profound learning at the interorganizational level, particularly since studies that consider the individual ad organizational levels are predominant and do not concern themselves much with OL and the role of the group, interorganizational and societal levels. Therefore they state that widening the scope to examine different role players at the different analysis levels, going beyond the organizational limits must go onto the agenda of future research thereby enabling advances in the field of knowledge.

Other studies such as those by Dierkes et al. (2001), Easterby-Smith et al. (2001) and Easterby-Smith and Lyles (2003), already mentioned bring a great contribution for learning studies, specially OL to revise the evolution of the area, highlighting differences in the literature and pointing out the need for more (an more profound) studies as to IOL. The Handbook of inter-organizational relations, published in 2008 also shows in its various chapters that there is a need to deepen studies concerning IOL.

IOL studies are multidisciplinary and the process dynamicity can only be made clear from this perspective. Thus, seeking better IOL comprehension it becomes necessary to understand the elements this level of learning consist of, highlighting the absorptive capacity, culture and context, trust and interaction, culmination in cooperation.

Considering the above it can be perceived that many variables affect the IOL, which shows it to be complex, nonetheless its importance cannot be doubted. Fayard (2008) corroborates this when he states that it is through interaction between agents beyond the operational borders that a collective learning environment is romoted. Therefore, facing the emerging reality (Estivalete et al., 2008; Mozzato, 2012; Mozzato \& Bitencourt, 2014), the field of research still requires theoretical studies, particularly of an empirical nature, such as those of MacDonald and Crossan (2010), that deal with the learning between different organizations.

\section{Legitimation of the Inclusion of the Fourth Level of Learning: IOL}

Exactly because IOL is a so far little explored field of analysis, there is justification for formalizing the inclusion of this learning level in studies on learning, legitimizing what has been dealt with by many authors. Thereby in order to propose a framework for IOL analysis in interorganizational relations it is relevant to recognize the importance of contributions by various previous studies, as well as to highlight the narrow relationship between OL and IOL.

Knight and Pye (2005), based on arguments by Crossan et al. (1995) and Knight (2002), conclude that the fourth level of the learning process is in network learning, by individuals or groups and organizations. Thereby they conceive network learning as what happens between a group of organizations as a group, through shared processes. For the purposes of this research it is this fourth level of learning that is being considered - an interorganizational level proposed by Crossan et al. (1995), and also, Bapuji and Crossan (2004), focusing on learning in and through relationships between organizations and different agents involved in interorganizational relationships.

In this context, initially the inclusion of the fourth level of learning the interorganizational one is proposed within the framework drawn up by Crossan et al. (1999) as to OL analysis (Figure 2), dealing with the fifth process at this level of cooperation. 


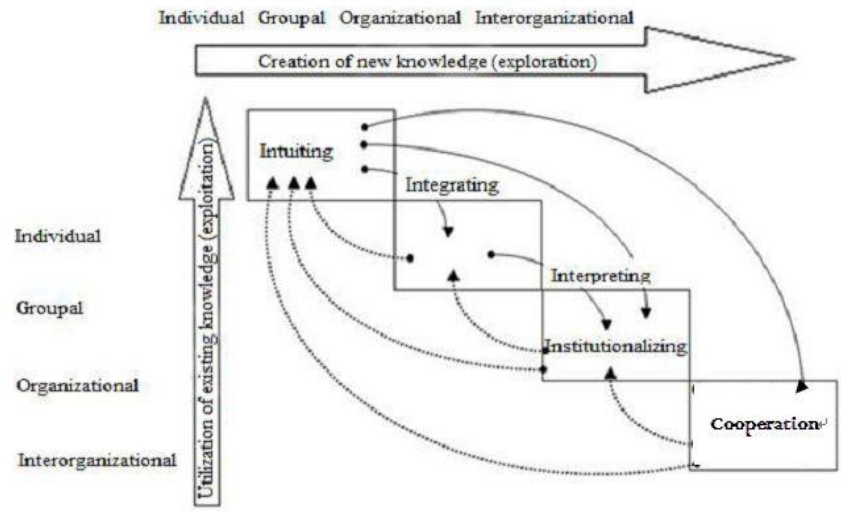

Figure 2. IOL as a dynamic process through cooperation

Facing the framework that has been proposed to understand IOL as a dynamic process through cooperation the fourth interorganizational level becomes explicit and the fifth level is cooperation. The interorganizational level refers to relationships established by the organizations beyond the organizational limit. The cooperation process is connected to relational strategies (suggested as being of cooperation) established between the different agents in interorganizational relationships.

The dynamic of the proposed framework is explained in a similar way in Crossan et al. (1999). Effectively up to the first three levels of learning and the four processes involved the author's explanations are adopted. However concerning OL as a level and OL as the fourth process included, even if the same logic is followed it must be stressed that intuition affects integration which affects interpretation and this last interferes with institutionalization. Therefore the latter interferes in cooperative processes. Consequently cooperation interferes in institutionalization, which interferes in interpretation and therefore in integration and finally in intuition.

This forwards and backwards dynamics leads to observing that learning occurs in OL throughout the four levels: individual, group, organizational and interorganizational. However IOL being included as a fourth level infers that the direct interference of intuition in institutionalization (proposed by Crossan et al., 1999) is transferred to cooperation. In this line of reasoning when the authors propose that institutionalization incides directly on intuition it can be understood that it is cooperation inciding directly on intuition. Besides, as they show, social and psychological processes permeate such levels. Mozzato and Bitencourt (2014) detail explain this fourth level of learning, working issues such as learning episodes and structured and non-structured social spaces at the level of cooperation.

By the same reasoning, using the table developed by Crossan et al. $(1999$, p. 525) to draw up Table 1, in which analytic categories are included for the interorganizational level of learning in the process of interorganizational relations. Nothing was altered in the first three levels and their respective analysis categories (entries) proposed by the authors, which lead to certain results.

Table 1. Learning/renewal in organizations: five processes through four levels

\begin{tabular}{lll}
\hline Level & Process & "Entries/ Results" \\
\hline Individual & Intuition & Experiences \\
& & Immages \\
\hline Group & Interpretation & Metaphors \\
& & Language \\
& & CognitiveMappiv \\
& & Dialogconversation \\
\cline { 2 - 3 } & Integration & Exchanges - \\
& & Mutual adjustment \\
& Interactive systems \\
\hline
\end{tabular}




\begin{tabular}{|c|c|c|}
\hline \multirow[t]{3}{*}{ Organizacional } & Institucionalization & Routines \\
\hline & & Dyagnostic systems \\
\hline & & Rulesand procedures \\
\hline \multirow[t]{5}{*}{ Interorganizacional } & Interorganizational relationships & Absorptioncapacity \\
\hline & & Culture/context \\
\hline & & Trust \\
\hline & & Interaction \\
\hline & & Cooperation \\
\hline
\end{tabular}

Source: Adapted from Crossan et al. (1999).

Table 1 refers to the interorganizational level of learning at the level of interorganizational relations. At this level the analysis categories (absorptive capacity, culture and context, trust and interaction) may result in cooperation relationships that enable interorganizational learning. Thus it is stated that the fifth process of the fourth level of learning is IOL. Thereby the four categories of analysis shown are subject to empirical investigation in different interorganizational configurations. Therefore, for purposes of theoretical elucidation it is a fundamental requirement to increase comprehension of the established analysis categories (absorption capacity, culture and context, trust and interaction), which is dealt with below.

As to the absorptive capacity, Levinson and Asahi (1995), Lane and Lubatkin (1998) and also Lane et al. (2001) show it as fundamental to IOL processes. Both Levinson and Asahi (1995) and Lane and Lubatkin (1998) state that a great part of the studies on IOL incide on the absorptive capacity, a term established by Cohen and Levinthal (1990), that means the ability to recognize, assimilate and apply new external knowledge. In view of this proposition the authors treat absorptive capacity as an IOL facilitating process. In this sense absorptive capacity shows cumulative characteristics facilitating the learning of further processes both intra and interorganizational. As stated by Nooteboom (2008), the absoption capacity consists of going beyond obtaining "competitor" information; the "competitor" must be able to understand it and convert it to knowledge. Trust culminates in facilitating the absorptive capacity (Cohen \& Levinthal, 1990), promoting greater IOL.

The trust category becomes a basic condition for effective IOL, which requires the establishment of the adequate balance between competition, cooperation, trust, stability and dynamism (Lane, 2001). As per Inkpen (2000), trust is a great facilitator of the exchange relations leading to knowledge becoming more accessible OL in the cooperation network. Both for Larsson et al. (1998) and Child (1999), mutual trust is a facilitator of the IOL process. As per Tsang (1999), trust is the mutual confidentiality between partners so that the vulnerabilities are not exploited by any of them. Inkpen and Tsang (2007) emphasize the fact that alliance partners use trust as a way of reinforcing their market competitivity and this is a key element.

Concerning the category culture and context, Levinson and Asahi (1995) stress the importance of culture and technology, both for IOL comprehension and management. By defining the types of learning in alliance Inkpen and Tsang (2007) state that the process of learning and results through this are influenced by various contextual factors: the form of the alliance, cultural questions, knowledge characteristics (the tree main aspects cited by the authors), alliance of the industry, competitivity and regulatory environment, industrial property agreements and control, the link between the network focus and the ample specter of collaborative relations. As to cultural questions Aun et al. (2005) consider the sociocultural values and high level of territorial identity extremely important maintaining and prospecting productive agglomerates admitting the importance of IOL. Also, studies like those by Sáenz et al. (2010) touch on the matter of enhanced performance through cultural alignment and IOL. Regional matters are dealt with by Yeung (2008).

Interaction, another analytic category refers to the capacity of interlinking various economic agents that maintain interorganizational relationships, comprising an important assumption for the occurrence of IOL. Thereby they become fundamental facilitators of interaction, increased connectivity, identity through common objectives and strong bonds and complementarity between those involved in interorganizational; relationships. To this end, Nooteboon (2008) states that the interaction between the different agents in an interorganizational is an important facilitating element for learning and innovation. Therefore the "close" interaction between the different agents is fundamental for the entire IOL process.

Therefore based on the proposals covered by Table 1 the corresponding theoretical proposals and authors taken into account in revising the four analytical categories under proposal are presented. Even though such matters 
can and must be dealt with in more depth through an empirical survey, presenting also conceptual elements for each category, the construction of learning at interorganizational level can already be represented which we do in Table 2.

Table 2. Construct IOL: definitions of the analysis categories

\begin{tabular}{|c|c|}
\hline Analytic Categories & Theoretical Proposals \\
\hline Absorptive capacity & $\begin{array}{l}\text { Term created by Cohen and Levinthal (1990), which means the capacity to recognize, assimilate and apply } \\
\text { new external knowledge. With this proposal the authors deal with the absorptive capacity as an IOL } \\
\text { facilitator. }\end{array}$ \\
\hline \multicolumn{2}{|c|}{$\begin{array}{l}\text { Reference Authors: Cohen and Levinthal (1990); Levinson and Asahi (1995); Lane and Lubatkin (1998); Larsson et al. (1998); Child } \\
\text { (2001); Lane et al. (2001); Inkpen and Tsang (2007); Villardi and Castro Junior (2007); Nooteboon (2008). }\end{array}$} \\
\hline Culture/context & $\begin{array}{l}\text { Characteristics associated with a place orregion in which interorganizational relations take place. It } \\
\text { consists of the social rationality that takes into account the capacities and potentialities that are inherent to } \\
\text { each place and/or new configuration. This cultural "alignment" increases the possibility of IOL. }\end{array}$ \\
\hline \multicolumn{2}{|c|}{$\begin{array}{l}\text { Reference Authors: Granovetter, (1985); Levinson and Asahi (1995); Nahapiet and Ghoshal (1998); Hardy et al. (2003); Greve (2005); } \\
\text { Aun et al. (2005); Capello and Faggian (2005); Inkpen and Tsang (2007); Hauser et al., (2007);Jones and Lichtenstein (2008); Kenis and } \\
\text { Oerlems (2008); Nahapiet (2008); Yeung (2008); Sáenz et al. (2010). }\end{array}$} \\
\hline Trust & $\begin{array}{l}\text { Reflects the conviction that the partner's word will be kept, consequently ensuring that the obligations of } \\
\text { the relationship will be performed directly influencing the IOL process. }\end{array}$ \\
\hline \multicolumn{2}{|c|}{$\begin{array}{l}\text { Reference Authors: Larson (1992); Perrow (1992); Inkpen and Beamish (1997); Ring (1997, 2008); Larsson et al. (1998); Child } \\
\text { (1999); Tsang (1999); Inkpen (2000); Lane (2001); Mohr and Singupta (2002); Woolthuis et al. (2005); Grandori and Cacciatori (2006); } \\
\text { Inkpen and Tsang (2007); Bachmann and Zaheer (2008); Gulati and Nickerson (2008); Nooteboom (2008); Lui (2009). }\end{array}$} \\
\hline Interaction & $\begin{array}{l}\text { Refers to the capacity of interaction between the various agents that maintain interorganizational relations, } \\
\text { an important assumption that ensures success in relationships, OLs and IOL processes. }\end{array}$ \\
\hline \multicolumn{2}{|c|}{$\begin{array}{l}\text { Reference Authors:Jarillo (1993); Larsson et al. (1998); Schmitz and Nadvi (1999); Aun et al. (2005); Greve (2005) Balestrin and } \\
\text { Verschoore (2008); Balestrin et al. (2008); Nahapiet (2008); Nooteboon (2008). }\end{array}$} \\
\hline Cooperation & $\begin{array}{l}\text { Consists of collaborative actions between different interorganizational agents that have reciprocal } \\
\text { commitments. Cooperative work assumes importance in view of the variety of positive effects of such } \\
\text { work processes. However it must be thought out in processes that can coexist with the competition. . }\end{array}$ \\
\hline \multicolumn{2}{|c|}{$\begin{array}{l}\text { Reference Authors: Granovetter (1985); Jorde and Teece (1989); Jarillo (1993); Brandenburger and Nalebuff (1996); Larsson et al. } \\
\text { (1998); Hardy et al. (2003); Shima (2006); Todeva (2006); Inkpen and Tsang (2007); Baiardi (2008); Balestrin and Verschoore (2008). }\end{array}$} \\
\hline
\end{tabular}

The construct of learning at interorganizational level presented here considers new parameters in learning investigation in present day organizations, OL while challenging organizational studies to widen their scope to understand the contents of relationships between organizations at the interorganizational level in different forms of networking organizations: LPAs, clusters and other.

\section{Final Considerations}

Considering that the widened scope for examining different agents at the different levels of analysis goes beyond organizational levels and it is art of a future agenda of research outlined for studies on OL (Crossan et al., 2011; Antonello; Godoy, 2009, 2010, 2011), IOL oriented researches are relevant. Although IOL raises many questions and research projects does not yet have a framework for understanding it in a continuum of individual, group, organizational and interorganizational learning. In view of the above it is clearly necessary to increase the analysis scope on IOL (Estivalete, 2007; Mozzato, 2012), this being seen as part of a continuum of organizational learning (Mozzato \& Bitencourt, 2014), a level identified by Crossan et al. (1995), but that was not included in the framework proposed by Crossan et al. (1999). It can be perceived that theoretical debate in this field of research highlights IOL as an emerging theme on which there are gaps in understanding, which may be filled with a framework proposal.

In view of the above, in an attempt to synthesize the propositions of this theoretical paper we stress that the objective of study is the interorganizational level of learning, legitimizing the one proposed by Crossan et al. (1995), Knight (2002), Bapuji and Crossan (2004), Knight and Pye (2005) and Crossan et al. (2011). Also, 
according to Crossan et al. (1999) reasoning, we head towards the presentation of analysis categories for the interorganizational dimension (absorptive capacity, culture and context, trust and interaction leading towards cooperation), which are the constructo for IOL analysis.

Thereby, according to the results of this study we aim at contributing to the advancement of knowledge on learning in the area of management, since it considers the least explored analysis level, interorganizational as well as the understanding of IOL in interorganizational relations. In view of the above shown it is understood that the study is relevant insofar as it con tributes to the understanding of learning at its four levels: individual, group, organizational and interorganizational.

Finally this theoretic study has achieved its objective in trying to legitimize the inclusion of the fourth level of learning, the interorganizational level. Even though the analytic constructor of IOL may and must be improved, with the possible inclusion of other pertinent constituting elements, but the first step has been taken.

\section{Acknowledgements}

The authors are grateful to the support received from the National Scientific and Technological Development Development Council - CNPq - Brazil.

\section{References}

Amato, N. J. A. (2000). Redes de cooperação produtiva e clusters regionais: Oportunidades para as pequenas e médias empresas. São Paulo: Atlas.

Amorim, W. A. C., \& Fischer, A. L. (2009). Aprendizagem organizacional: Uma análise sobre o debate e a escolha de categorias para estudos de caso. Perspectivas Contemporâneas, 4, 23-43.

Antonacopoulou, E., \& Chiva, R. (2007). The social complexity of organizational learning: The dynamics of $\begin{array}{llll}\text { learning and } & \text { organizing. } & \text { Management }\end{array}$ http://dx.doi.org/10.1177/1350507607079029

Antonello, C. S., \& Godoy, A. S. (2009). Uma agenda brasileira para os estudos em aprendizagem organizacional. $\begin{array}{lllll}\text { Revista de Administração de } & \text { de }\end{array}$ http://dx.doi.org/10.1590/S0034-75902009000300003

Antonello, C. S., \& Godoy, A. S. (2010). A encruzilhada da aprendizagem organizacional: Uma visão multiparadigmática. Revista de Administração Contemporânea, 1(2), 310-332.

Antonello, C. S., \& Godoy, A. S. (2011). Aprendizagem organizacional no Brasil. Porto Alegre: Bookman.

Argote, L. (2011). Organizational learning research: Past, present and future. Management Learning, 42(4), 439-446. http://dx.doi.org/10.1177/1350507611408217

Argyris, C., \& Schön, D. (1978). Organizational learning: A theory of action perspective. Workingham: Addison-Wesley.

Aun, M. P., Carvalho, A. M., \& Kroeff, R. L. (2005). Arranjos produtivos locais e sustentabilidade: Políticas públicas promotoras de desenvolvimento regional e da inclusão social. Alcance Univali, 12(3), 317-333.

Bachmann, R., \& Zaheer, A. (2008). Trust in inter-organizational relations. In S. Cropper, M. Ebers, \& C. Huxham (Eds.), The Oxford Handbook of inter-organizational relations. Oxford: University Press.

Baiardi, A. (2008). Competição e competição/cooperação. Organização \& Sociedade, 15(45). http://dx.doi.org/10.1590/S1984-92302008000200003

Balestrin, A., \& Verschoore, J. (2008). Redes de cooperação empresarial: Estratégias de gestão na nova economia. Porto Alegre: Bookman.

Balestrin, A., Vargas, L. M., \& Fayard, P. (2008). Knowledge creation in small-firm network. Journal of Knowledge Management, 12, 94-106. http://dx.doi.org/10.1108/13673270810859541

Bapuji, H., \& Crossan, M. (2004). From questions to answers: Reviewing organizational learning research. Management Learning, 35(4), 397-417. http://dx.doi.org/10.1177/1350507604048270

Bitencourt, C. C. (2001). A gestão de competências gerenciais: A contribuição da aprendizagem organizacional. Tese de Doutorado, Universidade Federal do Rio Grande do Sul, Porto Alegre, Brasil.

Bitencourt, C. C. (2005). Gestão de competências e aprendizagem nas organizações. São Leopoldo: Unisinos.

Brandenburger, A., \& Nalebuff, B. (1996). Co-opetição. São Paulo: Rocco.

Capello, R., \& Faggian, A. (2005). Collective learning and relational capital in local innovation processes. 
Regional Studies, 39(1), 75-87. http://dx.doi.org/10.1080/0034340052000320851

Cassiolato, J. E. (2004). Interação, aprendizado e cooperação tecnológica. Bogotá, Rediberoamericana de indicadores de ciência y tecnologia, p. 21 (Working Paper, Agosto).

Cassiolato, J. E., \& Lastres, H. M. M. (2003). O foco em arranjos produtivos e inovativos locais de micro e pequenas empresas. In H. M. M. Lastres, J. E. Cassiolato, \& M. L. Maciel (Eds.), Pequena empresa: Cooperação e desenvolvimento local. São Paulo: Relume Dumará.

Child, J. (1999). Confiança e alianças internacionais: O caso das joint ventures sino-estrangeira. In S. B. Rodrigues (Ed.), Competitividade, alianças estratégicas e gerência internacional. São Paulo: Atlas.

Child, J. (2001). Learning through strategic alliances. In M. Dierkes et al. (Eds.), Handbook of Organizatinal Learning \& Knowledge. Oxford University Press: New York.

Cohen, W. M., \& Levinthal, D. A. (1990). Absorptive capacity: A new perspective on learning and innovation. Administrative Science Quarterly, 35, 128-152. http://dx.doi.org/10.2307/2393553

Cropper, S. et al. (2008). The field of inter-organizational relations: A jungle or an Italian garden? In S. Cropper, M. Ebers, \& C. Huxham (Eds.), The Oxford handbook of inter-organizational relations. Oxford: University. http://dx.doi.org/10.1093/oxfordhb/9780199282944.001.0001

Crossan, M. M., Maurer, C. C., \& White, R. E. (2011). Reflections on the 2009 AMR decade award: Do we have a theory of organizational learning? The Academy of Management Review, 36(3), 446-460. http://dx.doi.org/10.5465/AMR.2011.61031806

Crossan, M., Lane, H., \& White, R. (1999). An organizational learning framework: From intuition to institution. The Academy of Management Review, 24(3), 522-537.

Crossan, M., Lane, H., White, R., \& Djurfeldt, L. (1995). Organizational learning: Dimensions for a theory. The International Journal of Organizational Analysis, 3, 337-360. http://dx.doi.org/10.1108/eb028835

Dierkes, M. et al. (2001). Handbook of Organizatinal Learning \& Knowledge. New York: Oxford University Press.

Easterby-Smith, M., \& Lyles, M. (2003). The blackwell handbook of organizational learning and knowledge management. Oxford: Blackwell Publishing.

Easterby-Smith, M., Burgoyne, J., \& Araujo, L. (2001). Aprendizagem organizacional: Oportunidades e debates atuais. In M. Easterby-Smith, J. Burgoyne \& L. Araujo (Eds.), Aprendizagem organizacional e organização de aprendizagem. São Paulo: Atlas.

Easterby-Smith, M., Lyles, M. A., \& Tsang, E. W. K. (2008). Interorganizational knowledge transfer: Current themes and future prospects. Journal of Management Studies, 45(4), 677-690. http://dx.doi.org/10.1111/j.1467-6486.2008.00773.x

Engestro, Y., \& Kerosuo, H. (2007). From workplace learning to inter-organizational learning and back: The contribution of activity theory. Journal of Workplace Learning, 19(6), 336-342. http://dx.doi.org/10.1108/13665620710777084

Estivalete, V. F. B., Pedrozo, E. A., \& Cruz, L. B. (2008). The learning process in interorganizational relationships. Brazilian Administration Review, 5(4), 319-331.

Estivalete,V. F. B. (2007). O processo de aprendizagem em redes horizontais do elo varejista do agronegócio: Do nível individual ao interorganizacional. Tese de Doutorado, Universidade Federal do Rio Grande do Sul, Porto Alegre, Brasil.

Fayard, P. (2008). Apresentação: A revolução gerencial das redes colaborativas. In A. Balestrin \& J. Verschoore (Eds.), Redes de cooperação empresarial: Estratégias de gestão na nova economia. Porto Alegre: Bookman.

Fiol, C. M., \& Lyles, M. A. (1985). Organizational learning. The Academy of Management Review, 10(4), 803-813.

Grandori, A., \& Cacciantori, E. (2006). Cooperation and competition in inter-firm projectos: The role of contractual and extra-contractual governance. In Egos Colloquium, 22, 2006, Bergen. Egos Conference PRoceedings, Center for Research on Business Organization - CRORA: Universitá Cocconi.

Granovetter, M. (1985). Economic action and social structure: the problem of embeddedness. American Journal of Sociology, 91(3), 481-510. http://dx.doi.org/10.1086/228311 
Greve, H. R. (2005). Inter-organizational learning and social structure. Organization Studies, 26, 1025-1047. http://dx.doi.org/10.1177/0170840605053539

Gulati, R., \& Nickerson, J. A. (2008). Interorganizational trust, governance choice, and exchange performance. Organization Science, 19(5), 688-708. http://dx.doi.org/10.1287/orsc.1070.0345

Hardy, C., Phillips, N., \& Lawrence, T. B. (2003). Resources, knowledge and influence: The organizational effects of interorganizational collaboration. Journal of Management Studies, 40(2), 321-347. http://dx.doi.org/10.1111/1467-6486.00342

Hedberg, B. (1981). How organization learn and unlearn. In P. C. Nystrom \& W. H. Starbuck (Eds.), Handbook of organizational design (pp. 3-27). Oxford: Oxford University.

Holmqvist, M. (2003). A dynamic model of intra and interorganizational learning. Organization Studies, 24, 95-123. http://dx.doi.org/10.1177/0170840603024001684

Holmqvist, M. (2004). Experiential learning processes of exploitation and exploration within and between organizations: An empirical study of product development. Organization Science, 15, 70-81. http://dx.doi.org/10.1287/orsc.1030.0056

Holmqvist, M. (2009). Complicating the organization: A new prescription for the learning organization? Management Learning, 40(3), 275-287. http://dx.doi.org/10.1177/1350507609104340

Human, S. E., \& Provan, K. G. (1997). An emergent theory of structure and outcomes in small-firm strategic manufacturing networks. Academy of Management Journal, 40(2), 368-403. http://dx.doi.org/10.2307/256887

Inkpen, A. C. (2000). Learning through joint ventures: A framework of knowledge acquisitions. Journal of Management Studies, 37(7), 1019-1045. http://dx.doi.org/10.1111/1467-6486.00215

Inkpen, A. C., \& Beamish, P. W. (1997). Knowledge, bargaining power, and the instability of international joint ventures. Academy of Management Review, 22, 177-202.

Inkpen, A. C., \& Tsang, E. W. K. (2007). Learning and strategic alliances. The Academy of Management Annals, l(1), 479-511. http://dx.doi.org/10.1080/078559815

Jarillo, J. C. (1988). On strategic networks. Strategic Management Journal, 9(1), 31-41. http://dx.doi.org/10.1002/smj.4250090104

Jarillo, J. C. (1993). Strategic networks: Creating the borderless organization. Oxford: Utterworth-Heinemann.

Jones, C., \& Lichtenstein, B. B. (2008). Temporary inter-organizational projects: how temporal and social embeddedness enhance coordination and manage uncertainty. In S. Cropper, M. Ebers \& C. Huxham (Eds.), The Oxford handbook of inter-organizational relations. Oxford: University Press.

Jorde, T. M., \& Teece, D. J. (1989). Competition and cooperation: Striking the right balance. Business \& Public Policy, Spring.

Kenis, P., \& Oerlemans, L. (2008). The social network perspective: Understanding the structure of cooperation. In S. Cropper, M. Ebers \& C. Huxham (Eds.), The Oxford handbook of inter-organizational relations. Oxford: University Press.

Knight, L. (2002). Network learning: Exploring learning by interorganizational networks. Human Relations, 55, 427-454. http://dx.doi.org/10.1177/0018726702554003

Knight, L. (2005). Network learning: An empirically derived model of learning by groups of organizations. Human Relations, 58(3), 369-392. http://dx.doi.org/10.1177/0018726705053427

Lane, C. (2001). Organizational learning in supplier networks. In M. Dierkes et al. (Eds.), Handbook of organizatinal learning \& knowledge (pp. 733-752). New York: Oxford University Press.

Lane, P., \& Lubatkin, M. (1998). Relative absorptive capacity and interorganizational learning. Strategic Management Journal, $461-477$. http://dx.doi.org/10.1002/(SICI)1097-0266(199805)19:5<461::AID-SMJ953>3.0.CO;2-L

Lane, P., Salk, J., \& Lyles, M. (2001). Absortive capacity: Learning and performance in international joint ventures. Strategic Management Journal, 22(12), 1139-1161. http://dx.doi.org/10.1002/smj.206

Larson, A. (1992). Network dyads in entrepreneurial settings: A study of the governance of exchange relationships. Administrative Science Quarterly, 37(1), 76-104. http://dx.doi.org/10.2307/2393534 
Larsson, R., Bengtsson, L., Henriksson, K., \& Sparks, J. (1998). The interorganizational learning dilemma: Collective knowledge development in strategic alliances. Organization Science, 9(3), 285-305. http://dx.doi.org/10.1287/orsc.9.3.285

Levinson, N., \& Asahi, M. (1995). Cross-national alliances and interorganizational learning. Organizational Dynamics, 24(2), 50-64. http://dx.doi.org/10.1016/0090-2616(95)90071-3

Lubatkin, M., Florin, J., \& Lane, P. (2001). Learning together and apart: A model of reciprocal interfirm learning. Human Relations, 54(10), 1353-1382.

Lui, S. S. (2009). The roles of competence trust, formal contract, and time horizon in interorganizacional learning. Organization Studies, 30, 333-353. http://dx.doi.org/10.1177/0170840608101139

MacDonald, P., \& Crossan, M. (2010). Learning to innovate: The process of learning between diverse organizations. In Organization Learning, Knowledge and Capabilities Conference, 5, 2010, Boston. Boston: Northeastem Univesity.

Mozzato, A. R. (2012). O processo da aprendizagem interorganizacional: Proposição de esquema conceitual analítico para sua compreensão em contexto de APL. (Tese de Doutorado), UNISINOS, São Leopoldo, Brasil.

Mozzato, A. R., \& Bitencourt, C. C. (2014). Understanding interorganizational learning based on social spaces and learning episodes. BAR - Brazilian Administration Review, 11(3). http://dx.doi.org/10.1590/1807-7692bar2014370

Nahapiet, J. (2005). The role of social capital in inter-organizational relationships. In S. Cropper, M. Ebers \& C. Huxham (Eds.), The Oxford handbook of inter-organizational relations. Oxford: University Press.

Nahapiet, J., \& Groshal, S. (1998). Social capital, intellectual capital and the organizational advantage. Academy of Management Review, 23(2), 242-266.

Nooteboom, B. (2008). Learning and innovation in inter-organizational relationships. In S. Cropper, M. Ebers \& C. Huxham (Eds.), The Oxford handbook of inter-organizational relations. Oxford: University Press.

Perrow, C. (1992). Small-firm networks. In N. Nohria \& R. Eccles (Eds.), Network and organizations: Structure, form and action. Boston: Harvard School.

Pittaway, L. et al. (2004). Networking and innovation: A systematic review of the evidence. International Journal of Management Reviews, 5/6(3-4), 137-168. http://dx.doi.org/10.1111/j.1460-8545.2004.00101.x

Powell, W. (1998). Learning from collaboration: Knowledge and networks in the biotechnology and pharmaceutical industries. California Management Review, 40, 228-240. http://dx.doi.org/10.2307/41165952

Ring, P. (1997). Processes facilitating alliance on trust in inter-organization networks. In M. Ebers (Ed.), The formation of inter-organizational network. Oxford: Oxford University.

Ring, P. (2008). Theories of contract and their use in studying inter-organizational relations: Sociological, psychological, economic, management, and legal. In S. Cropper, M. Ebers \& C. Huxham (Eds.), The Oxford handbook of inter-organizational relations. Oxford: University Press.

Ruas, R., Antonello, C. S., \& Boff, L. H. (2005). Os novos horizontes da gestão: Aprendizagem organizacional e competências. Porto Alegre: Bookman.

Saenz, M. J. et al. (2010). Enhancing supply chain performance through cultural alignment and interorganizational learning. In Organization Learning, Knowledge and Capabilities Conference, 5, 2010, Boston. Boston: Northeastem Univesity.

Schmitz, H., \& Nadvi, K. (1999). Clustering and industrialization: Introduction. World Development, 27(9), 1503-1514. http://dx.doi.org/10.1016/S0305-750X(99)00072-8

Shima, W. T. (2006). Economia de redes e inovação. In V. Pelaez \& T. Szmrecsányi (Eds.), Economia da inovação tecnológica. São Paulo: HUCITEC/Ordem dos Economistas do Brasil.

Takahashi, A. R. W. (2007). Descortinando os processos da aprendizagem organizacional no desenvolvimento de competências em instituições de ensino. Tese de Doutorado, Universidade de São Paulo, São Paulo, Brasil.

Todeva, E. (2006). Business networks: Strategy and structure. London: Toutledge. 
Tsang, E. W. K. (1999). A preliminary typology of learning in international strategic alliances. Journal of World Business, 34, 211-229. http://dx.doi.org/10.1016/S1090-9516(99)00016-4

Villardi, B. Q., \& Castro Junior, J. L. P. (2007). Emocionalidade limitada: Uma dimensão da aprendizagem coletiva para desenvolver relações cooperativas e solidárias em arranjos produtivos locais: os casos. Cadernos EBAPE, 5(2), 1-15. http://dx.doi.org/10.1590/S1679-39512007000200007

Woolthuis, R., Hillebrand, B., \& Nooteboom, B. (2005). Trust, contract and relationschips development. Organization Studies, 26(6), 813-884. http://dx.doi.org/10.1177/0170840605054594

Yeung, H. W. (2008). Perspectives on inter-organizational relations in economic geography. In S. Cropper, M. Ebers \& C. Huxham (Eds.), The Oxford handbook of inter-organizational relations. Oxford: University Press.

\section{Copyrights}

Copyright for this article is retained by the author(s), with first publication rights granted to the journal.

This is an open-access article distributed under the terms and conditions of the Creative Commons Attribution license (http://creativecommons.org/licenses/by/3.0/). 